\title{
The Use of Logic in Contemporary Islamic Discourses
}

\author{
Shahir Akram Hassan \\ Centre For Islamic Development Management Studies (ISDEV), Universiti Sains Malaysia, Pulau Pinang \\ Email: shahirakram@usm.my/shahir_isdev@yahoo.com
}

\section{Doi:10.5901/mjss.2016.v7n5p171}

\begin{abstract}
In a fluid and ever changing global environment, the need to rationally engage and logically address the controversies that challenge the sanctity of Islam is an ubiquitous feature of contemporary times. As the challenges confronting Islamic thinkers are diverse and manifold, there is an urgent need for an advocacy approach that is premised on the rational application of Logic in Islamic Discourse. Nevertheless, the current approach of totally relying on Logic as a tool to elucidate the problems and controversies besetting the Ummah is replete with numerous shortcomings as evidenced by the advent of deviationist ideologies inimical to Islam such as pluralism, liberalism, and feminism. This paper purports to examine the nature of Logic within Islamic Discourse and how it is applied to not only portray Islam but to also delineate and clarify its adequacy in addressing contemporary issues and controversies bedeviling the Ummah. In seeking answers to these questions, the paper first sought to explicate upon the nature of Logic within the realm of knowledge. Next, it analyzed the use of logic in contemporary Islamic discourse. A qualitative approach which basically encompasses library research was utilized to obtain secondary data regarding the use of logic in contemporary Islamic discourse. Subsequently, the collated data was subjected to textual analysis. The findings reveal that there are at least two approaches that underpin the use of logic in Islamic discourse, namely, the reason (aql) based and the revelation (wahyu) based approaches with both approaches having their respective outcomes. Based on the analyzed data, the study recommends that the application of logic in contemporary Islamic Discourse should be premised upon on a hybrid approach named Contemporary Islamic Logic Approach (CILA) that draws its synergy from the revelation based approach but manifests itself via aql based arguments whilst simultaneously complying with four basic rules i.e., possessing a clear Islamic epistemology and tasawur, utilizing Islamic reasoning approaches, strengthening the Islamic framework and finally, emphasizing the means aspect of Western Logic rather than its end.
\end{abstract}

Keywords: Conflict, Logic, Islamic Logic, Reasoning Methods, Islamic Discourse

\section{Introduction}

Lately, many problematic issues have arisen that demand immediate clarification from contemporary Islamic scholars. Such issues revolve around the massacre of innocent civilians in the name of jihad by the Islamic State (ISIS), the caricatures of the Holy Prophet by the satirical magazine Charlie Hebdo under the guise of freedom of speech and the struggle to legitimize the rights of Lesbians, Gays, Bisexuals and Transgender (LGBT) cohorts under the pretext of upholding human rights. Such contemporary controversies come on the heels of other longstanding polemics consistently engendered and championed by the intelligentsia. These polemics include Liberal Islam, religious pluralism, feminism and the anti-hadith movement.

The questions that arise in confronting these manifold challenges include the adequacy of existing Islamic epistemological frameworks in addressing these issues, whether the clarifications and explanations provided are able to satisfy and resolve confusion and whether there exist inadequacies in both argumentation and ratiocination methodologies currently deployed.

To answer the above questions, the paper will focus on two main objectives, namely, identifying the use of logic in contemporary Islamic Discourse and analyzing the utilization of logic in contemporary Islamic Discourse. This paper will be divided into four sections. Section 1 will delineate the role of Logic as the yardstick for assaying Reality while section 2 will highlight the key features of Contemporary Islamic Discourse. Section 3 will evaluate the potentiality of amalgamating Western Logic algorithms into contemporary Islamic while Section 4 will outline features of the hybrid model proposed before drawing the relevant conclusions.

\section{Logic}

The term 'logic' traces its origins to the Greek term logos. Essentially, 'logic' refers to the judicious and objective application of Reason, the outcomes of which are manifested via speech and expresssed through language. (Abdul 
Rahman Abdullah 2007). Logical knowledge is synonymous with the capacity to think in a systematic, precise and linear trajectory and is often regarded as a precursor to effective thinking and the ability to cognitively comprehend an issue rationally. Generally, if a rationale proffered to reinforce a fact is rationally sound/acceptable, it will be deemed as logic (Hamidah Abdulhamid 1991).

Basically, the verb for Logical Knowledge is 'ratiocinate' or 'reasoning' while its nominalized form is 'ratiocination'. Reasoning here refers to the imperceptible evolution of thought via a series of statements deemed to be true that eventuates in the formulation of a fact. In other words, the reasoning approach is both an evidence and argumentationbased approach that aspires towards the attainment of an outcome that affirms Truth. Reasoning has a critical function in both research/critical enquiry and argumentation as it defines the strength or otherwise of a particular enquiry or argumentation (Muzaffar lqbal 2009). Therefore, it is imperative that any exercise of reasoning be guided by specific procedures to avoid faulty reasoning and argumentation. In other words, a well-structured and logical reasoning approach is the precursor towards clear, precise, efficient and effective thinking that will ensure that sound decisions are derived and correct choices made. Consequently thought, enquiry, and action derived from a correct reasoning approach will yield outcomes that are both equitable and good (Lok, Gan \& Ratna Roshida Ab Razak 2009).

The utilization of the systematic thought approach in investigating and contemplating a phenomenon is traceable to the era of Thales in $6^{\text {th }}$ century BC (Russell 1993). Thales was a Greek philosopher who eschewed myth and superstition. Instead, he embraced reasoning and common sense as his tools to contemplate about and resolve the inscrutable mysteries of Nature (Hamidah Abdul Hamid 1991).

Thales employed a number of novel reasoning approaches. Amongst them was the logical inductive method which he utilized to validate his assertion that all organisms on Earth originated from water. Water was postulated to be the fountain of Life on the grounds that water was the soul of each and every living being. In Thales' logical perspective, water was the soul of plants as without water, plants would shrivel and die. Similarly, water was the life force of animals and humans as Man could not survive without water despite being deprived of food. Given that even water vapor originated from water, Thales inductively reasoned that Water was the life force of all living things (Mayer 1950).

After the advent of Thales's logical reasoning approach, the Greeks soon expanded their skills in analytical thought, the organization of knowledge and argumentation strategies. Amongst the foremost logicists of the era were Socrates, Plato and Aristotle (Russell 1993; Mat Rofa Ismail 1994).

Socrates valorized logic both as a science and for its theoretical/hypothesizing potential. Alloyed by this conviction, Socrates delineated Logic as common sense. According to Socrates, Truth was the ultimate goal of hypothesizing. Consequently, he emphasized moral responsibility in his argumentation The main process deployed by Socrates in his argumentation was the analytical process (Hamidah Abdulhamid 1991; Abdul Rahman Abdullah 2007).

The analytical foundations for Logic as mapped out by Socrates were expanded upon by his student, Plato (Mat Rofa Ismail 1994). Plato, who introduced the synthetic method, averred that for Logic to seek consanguinity with Science, an individual should distance their common sense from personal prejudice and subjective inclinations (Russell 1993). This postulate, now known as objectivity, heralded an acceleration in the development of Logic fueled as it was by a thirst for knowledge and an earnest quest for Truth, both of which contributed towards the accumulation of data/material facts as well as the generation of theories. Nevertheless, these theories were critiqued by Aristotle.

Aristotle, in critiquing Plato contended that the theories and their associated terminologies deployed in the objective approach were inherently vague (Barnes 1991). For instance, Aristotle, in elucidating the term 'sharp', noted that its denotative meaning could be manifold i.e., a sharp knife, a sharp rebuke or being of sharp hearing. Guided by this heuristic, Aristotle formulated a systematic mode of thinking designed to eliminate faulty logic, fallacies and ambivalence during the thought process.

Leveraging upon the fundamentals established by Socrates and Plato, Aristotle proceeded to formulate new principles and techniques in reasoning that eventually formed the basis for Logic as it is contemporarily perceived (Walbridge 2011; Sulaiman Noordin 1992). One of the procedures instituted by Aristotle involved the introduction of deductive logic which was essentially syllogistic in nature. Basically, Syllogism comprises three premises i.e., the main premise, its subset and a conclusion. (H. Syukriadi Sambas 1996). An illustration of the principles of Syllogism is evident in the following example:

All men are mortal (main premise)

Socrates is a man (subset of main premise)

Therefore, Socrates is mortal (conclusion)

Aristotle was careful to stress that there was no connection between Logic and the underlying Truth of the 
proposition being propounded. He further expounded that if the proposition being used was true, then any conclusion so derived from it would invariably be true. Alternatively, if the proposition used was false, any conclusion drawn from it would inevitably be false (Russell 1993). In other words, Logic was merely an approach and a tool to determine whether a postulation subjected to argumentation would yield a true conclusion.

Given its systematic approach, Aristotle's conceptualization of Logic was soon widely accepted and applied in his era. In fact, it was used as a guideline for judicious hypothesizing and to support theory. Nevertheless, there have been instances of deviation in the application of Aristotle's Logic framework subsequent to its widespread acceptance with the use of false premises to support theories being the prime infraction. Occasionally, true premises were also employed either to generate or support false conclusions. The group responsible for using these fallacies to support their theories or draw dubious conclusions therein was known as the Sophists (Russell 1993). Despite these deviations, Aristotle's Logic was saved by the advent of Christianity.

Early Christianity's influence was largely responsible for the rejection of the patently paradoxical and ambivalent conjectures applied by the Sufastah in their argumentations. Furthermore, the spread of Christianity ensured the consolidation of truth and facts within the Logic paradigm which by default diminished the influence of myth and fallacies. The ensuing vacuum was filled by Christianity which utilized Logic as a means to streamline and rationalize Christian thought (Hamidah Abdulhamid 1991). The ascendancy of Christianity within the realms of Logic was opposed by those who valorized Science and were skeptical of the esoteric content of Christianity. Amongst the early dissenters was Sextus Empiricus (Walbridge 2011 \& Russell 1993) who was one of the early pioneers of Skepticism. In response, the Church decreed that Skepticism was in direct contradiction of the Church's teachings as the Church posited that faith and skepticism were mutually incompatible abstractions (Russell 1993).

Another group that emerged during this period were the Scholastics who underwent a perceptible shift in their epistemology over three eras. The first era was devoted to leveraging upon Logic as an instrument to justify religious ideology while the second era witnessed the further refinement of both religion and philosophy, an iterative process that gave birth to Realism. The final era saw the formal split of religion and philosophy, an event that yielded normalism. As each of these eras generated different thought heuristics, confusion and polemics were common (Walbridge 2011).

At the same time, Logic had also expanded to other continents and regions such as the Arabian Peninsula where the underlying principles and procedures governing Logic was translated into the native language i.e., Arabic by Ibn Muqaffa' (Mat Rofa Ismail 1994; Abdul Rahman Abdullah 2010 \& Walbridge 2011). Subsequent initiatives to expand the reach of Logic were initiated by al-Kindiy, al-Farabiy, Ibn Sina and Ibn Rushd (Mat Rofa Ismail 1994). During this initial phase, these scholars merely received and translated works on Logic into Arabic. This new branch of knowledge was known as Islamic logic (Hairuddin Harun 1992).

Initially, the study of Islamic logic was not officially sanctioned by Muslim jurists. In fact, Muslim jurists/scholars were divided into three schools of thought regarding the study of Islamic logic. The first school of thought as represented by Ibn Solah, Ibn Taymiyyah (2005), al-Nawawiy and Imam Suyutiy expressly prohibited the learning of Islamic logic (Sa'id Fudah 2002); the second school helmed by luminaries like al-Ghazaliy deemed the study of Islamic logic as permissible. Finally, a third group consisting of Sunni and Sufi scholars stridently opposed any edict that proscribed the learning of Islamic logic (H. Syukriadi Sambas 1996 \& al-Shanqiti 2007).

However, it should be noted that the prohibition on learning Islamic logic was not a blanket proscription. Rather, the edicts that barred any such learning were more directed at the study of Islamic logic that had been influenced by Greek philosophy or the study of Islamic Islamic logic contaminated by the Grecian worldview. On the other hand, Muslim jurists/scholars were of the consensus that the study of Islamic logic sourced from Islamic precepts or Islamic logic absent of philosophical influences was permissible (H. Syukriadi Sambas 1996; Mohd Fauzi Hamat 2005).

Subsequent to the comprehension and mastery of Islamic Logic, a number of Muslim scholars embarked on a critique of Greek Logic's underlying principles. Amongst the most vocal critics of the Greek school were Ibn Taymiyyah (2005) and al-Ghazaliy. Interestingly, Al-Ghazaliy (1993) whilst critiquing the deviationist nature of Greek philosophy and logic in Tahafut al-Falasifah, nevertheless employed an argumentative approach that was redolent of the ratiocinative approach underpinning Greek Logic (Mohd Fauzi Hamat 2005).

In actuality, al-Ghazaliy (1993) never deployed Greek Logic directly. Instead, he used it as a reference point to design a framework that was consistent with the precepts of Islam and utilized this framework for the benefit of Islamic knowledge. As evidence, al-Ghazaliy (undated) penned a treatise on Islamic logic in the introduction to al-Mustasfa, a tract on Islamic Law (figh). In fact, prior to al-Ghazaliy, another scholar, al-Shafi'iy (undated) had already delineated several reasoning approaches in another tract on Islamic Law entitled al-Risalah. In his treatise, Al-Shafi'iy (undated) outlined detailed approaches for comprehending Quranic verses. Eventually, these approaches and principles underwent a process of development, refinement, and iteration and gradually coalesced into the framework which we now term as 
'Islamic Logic'. Subsequently, Islamic logic was applied in other branches of Islamic knowledge such as dialectical theology and Islamic Jurisprudence (Mohd Fauzi Hamat 1996; Ya'qub al-Bahuthain 1998 \& 2001).

Although, Greek intellectual influences spread rapidly into both the Arab and the Islamic world, this did not prevent the emergence of different modes of thinking. Amongst these modes was that of Francis Bacon. Bacon, who disagreed with the Greek approach to Logic, expounded that experimentation via observation was one of the methods that should be utilized to reflect upon and affirm Truth/Reality (Hamidah Abdulhamid 1991). Bacon (1955) in propounding an alternative idea to the deductive method introduced a new approach, namely the inductive approach which he explicated in his book, Novum Organum Scientiarum.

Essentially, Bacon's inductive logic is premised on a framework that was in direct apposition to the framework underpinning the deductive approach (Mat Rofa Ismail 1996). This is because the inductive approach used specific cases to formulate a general conclusion. For instance, Bacon used the results of experiments conducted by others to assist him in formulating general laws regarding the universe. He further postulated that apart from the natural world, there existed another world which he christened 'the world of thought' (Hamidah Abdulhamid 1991).

Bacon's central hypothesis revolved around his perception that Reality could be apprehended via his Idols of the Mind concept. Nevertheless, he also acknowledged that there were four constraints impeding the attainment of such logical clarity regarding Reality. He defined these four constraints as idols of the tribe, idols of the cave, idols of the market place and idols of the theatre (Abdul Rahman Abdullah 2010; Weathington, Cunningham \& Pittenger 2010). Bacon's valorization of the inductive approach is indicative of his negation of earlier approaches and frameworks to perceiving Reality besides affirming his attachment to the empirically driven and observable experimental approach. It would be this predilection for the tangible and the observable that would eventually drive philosophers like Bacon to reject spirituality.

Mills (1850) would further affirm the inductive approach in his book, System of Logic. Additionally, the inductive approach to Logic was further enriched by the contributions of pioneer symbolists such as Gottfried Wilhelm Leibniz who arranged algebraic logic based on the Ars Magna of Raymundus Lullus in order to simplify the task of common sense and further enhance certitude.

Chares Sanders Peirce completed the symbolic logic paradigm via his works wherein he introduced Peirce's Law which interpreted logic as a general theory of signs. The apogee of the symbolic logic movement's achievements was attained with the publication of three editions of Principia Mathematica between 1910-1913. It is evident from the foregoing that Bacon, Mills, Peirce and a host of other scholars played an influential role in formulating research frameworks that emphasized the Ratiocination approach (Abdul Rahman Abdullah 2010).

The long history of Logic proves unequivocally that classical knowledge, Islamic knowledge and western knowledge each possessed unique yardsticks to apprehend and measure Truth. This yardstick was evidently Logic (Gabbay \& Woods 2008), the selfsame yardstick that informed contemporary Islamic Discourse.

\section{Contemporary Islamic Discourse}

In contemporary Islamic discourse, there are two modes by which contemporary issues are dissected namely Traditional Islamic Logic and Western Logic.

\subsection{Traditional Islamic Logic}

Islam possesses its own epistemology of logic. It is called Islamic Logic and consist of three main approaches. They are tasawwur, tasdiq and al-istidlal. Tasawwur centred discussions embrace five approaches dilalah; 'alfaz; kulliyyat alkhams; al-ta'rif and nisbah. Tasdiq centred discussions are focused upon qadiyyah i.e. statements. Qadiyyah in turn is made up of qadiyyat hamliyyah and qadiyyath shartiyyah. The final approach namely al-istidlal comprises both direct ratiocination approaches and indirect ratiocination approaches. Direct ratiocination are effected through taqabal and 'akas while indirect ratiocination are realized via qiyas, istiqra' and tamthil. Within the context of ratiocination there are also discussions regarding the division of argumentation in Islamic logic. Essentially, Islamic Logic is a branch of Islamic knowledge that is premised on two types of arguments which is Revelation (Naqli) based argumentation and Reason (aqli) based argumentation. This branch of knowledge was subsequently used by Islamic scholars to construct or disseminate traditional Islamic knowledge (Gabbay \& Woods 2008).

Islamic Logic oriented argumentation has long existed in each branch of traditional Islamic Knowledge namely, aqidah (faith), figh (law) or tafsir (interpretation). For instance, aqidah which is devoted to the discussion of the Unseen and Logos, derives its knowledge from three sources namely the sensory organs, revelation and thought (al-Sa'diy 2008). 
This clearly implies that in Islam, any dissection of knowledge is obliged to refer to revelation although the roles of sensory perception (panca indera) and thought (aqli) are also acknowledged. Hence, discussions in matters of faith regarding belief in Allah SWT or belief in the message of the Prophets and the Messengers are invariably commenced by Revelation (naqli) based ratiocination (Al-Qur'an and hadith) before gravitating to Reason (aqli) based ratiocination.

In Islamic Law (Figh) discussions, the writings of Muslim scholars are also premised on Islamic Logic. Hence, tracts on Islamic Law invariably commence with the elucidation of concepts, the provision of definitions based either on linguistic or terminological parameters, explications on tenets, obligatory conditions and the wisdom of legislation. Additionally, any argumentation of Islamic Laws are to be be guided by the methodology of deriving edicts from postulates/evidence in the respective disciplines or branches of Islamic Logic (the evidence meant in the aforementioned definitions are from consensually agreed upon figh sources such as the al-Qur'an, al-Sunnah (Traditions of the Prophet), ijma' (scholarly consensus) and qiyas (allusions) or from sources non- consensually agreed upon figh sources such as Istihsan (the application of discretion), Istishab (the principle of continuity), Maslahah (public interest) Qawa'id Fiqhiyyah (legal maxims).

In the area of interpretation (tafsir), there have been attempts by scholars to compile an exegesis using Islamic Logic as its foundational framework in order to complement Quranic exegesis/commentaries such as tafsir bi al-ma'thur (report-based commentary), tafsir bi al-ra'yi (commentary based on personal interpretation), tafsir al-fiqhi (commentary based on juristicinterpretation) and tafsir al-ishari (commentary based allegorical interpretation) that were derived from other Islamic methodologies or ontological frameworks. Amongst the commentaries that adopts the Islamic Logic approach in its methodology is Imam al-Raziy's tafsir Mafatih al-Ghayb (the Key to the Unknown).

Generally, the process of ratiocination in Islam is constructed from Islamic Logic. It then expanded into specific frameworks appropriate for the disciplines under scrutiny. Unfortunately, this approach is restrictive in that it cannot dissect and clarify contemporary issues as any such dissection or clarification is bounded by the principles established by the various Islamic disciplines which in any case are generally inaccessible due to their esoteric nature. Consequently, any explanation proffered invariably failed to resolve the contemporary problem being studied. Consequently, contemporary Islamic Discourse has embraced Western Logic approaches to resolve this conundrum.

\subsection{Western Logic}

Basically, western logic tries to infuse modes of thinking perceived to be consanguineous with contemporary needs and that emphasises both objectivity and problem solving. Problem solving is by default linked to Logical Thinking wherein the adjectival form 'logical' is synonymous with clear or valid reasoning and is described as flowing necessarily from facts or events. Conversely, 'illogical' is regarded as referring to any absurdity that is deemed senseless and unreasonable (Teare 2006). On the other hand, objectivity is conceptualised as a yardstick that ensures consistency in the thinking process in the quest to ascertain Truth (Kelley 1998), and that identifies the relationships between cause and effect in collated data (Myrdal 1969). Both these constructs of objectivity form the basis of Western thought and also constitute the core of numerous philosophical paradigms such as positivism, hermeneutics etcetera. These philosophical constructs bind the contemplation of Truth/Reality to objects that are observable and analysable by our sensory perceptions besides granting complete freedom to the mind to elucidate Truth without any reliance whatsoever on revelatory guidance (Reevany Bustami, Eleesya Nasruddin \& Norman Blaikie 2006).

Despite the glaring spiritual deficiency, the Western Logic approach was widely embraced by a significant segment of Muslim society, particularly alumni of Western tertiary institutions and those from the professional class due to it striking a responsive and empathetic chord in the minds of those seeking solace and answers for their contemporary needs. Thus, their yearning for Islam, in actuality was for a Deen that could be perceived and understood from the seemingly rational and objective Western Logic paradigm, a paradigm that facilitated the evaluation Truth/Reality via sensory perception and tangible observation. The net outcome of this yearning was the rise in worldviews inimical to the precepts of Islam such as liberal Islam, pluralism, feminism and the anti-hadith movement. To surmise, the misguided embrace of the spiritually bereft Western Logic paradigm not only fomented confusion and doubts regarding the religion amongst the Ummah itself but from a different perspective, implicitly signaled an attack against the Islamic worldview.

There are several issues that need to be highlighted if one intends to utilise them in research pertaining to Islam and the Ummah. Issues such as objectivity, being bound to the principles of cause and effect that could plausibly endanger faith, the lack of instruments to analyse natural and metaphysical phenomena, discoveries that do not necessarily represent knowledge about Reality need to be further refined and clarified (Shahir Akram Hassan 2011). One proposed framework within which these issues can be dissected further from an Islamic perspective is the Contemporary Islamic Logic approach (CILA). 


\section{The Use of Logic in Contemporary Islamic Discourse}

From the preceding discussion, we can surmise the following regarding Contemporary Islamic Discourse.

Contemporary Islamic Discourse tends to discuss contemporary issues within the Western Logic framework on the grounds that this framework is perceived to be problem solving, rational in its argumentation, capable of being evaluated by sensory perceptions and is objective in its orientation. Moreover, such an approach is perceived to be more persuasive and convincing to the non-Muslims due to the argumentation methodology that underpins it. However, such an assumption is self-defeating to Islam itself.

This reliance on the Western Logic framework to analyse and resolve contemporary issues stems from the inherent tendency of Islamic Logic to scrutinise a contemporary issue from an intellectual perspective within the narrow and sometimes ossified confines of traditional Islamic Knowledge. Consequently, there is a dearth of practical solutions to the problem as well as a dearth in well-reasoned, eloquent and acceptable arguments/rhetoric. In other words, whilst discussions from an intellectual angle are existent and gradually growing, empirically, no viable solutions are proffered to address a contemporary need.

Hence, there is a need for a transformation in current approaches in presenting Islam particularly in the research and writings of Muslim intellectuals given the constantly evolving and dynamic global paradigm. In other words, Islamic Logic must evolve in keeping with changing times. Essentially, this entails the preservation of Islamic logic and traditional Islamic knowledge given their proven and established approaches whilst argumentation norms and presentation are realigned to satisfy the needs and reasoning capabilities of contemporary citizenries irrespective of their religious affiliations. In other words, a contempoary citizenry demands a contemporary framework of engagement. One such framework that can be considered is the Contemporary Islamic Logic Approach (CILA). In fact, such an approach could function as a mediator bridging the Traditional Islamic Logic and the Western Logic approaches.

In confronting contemporary issues, the proposed Contemporary Islamic Logic Approach should take into consideration four aspects as delineated in the following paragraphs.

Firstly, the argumentation algorithms used must possess an Islamic episteomology and tasawwur that is clear. In analysng and debating about contemporary issues, Islamic tasawwur shoud be identified by utilising an Islamic epistomology. Generally, Tasawwur is a disputation regarding concepts. Concepts are intellectual tools utilized to identify individual objects that collectively define Reality. Hence, a concept of an object is a mental representation of the selfsame object. In other words, the term 'concept' refers to what is understood by Reason pertaining a given object hence, an understanding of an object or its conceptuality implies that an individual should apprehend the components that form the object.

In Islamic logic theory, in order to precisely apprehend an object, an individual must at least be able to observe it via five approaches namely dilalah; alfazh; kulliyyat al-khams; al-ta'rif and nisbah (Ahmad Damanhuri 2006; Al-Shanqiti 2007; Murtadha Mutahhari 2011). This explains why when one discusses a western concept such as poverty, wealth management, Corporate Social Responsibility (CSR) etcetera, one is obliged to redefine the aforementioned concepts so as to ensure that the discussion and explications pertaining them are correct from an Islamic perspective (Muhammad Syukri Salleh 2013)

Secondly, there is a need to consistently utilize and adhere to the Islamic Reasoning approach. Abdul Hadi alFadhli (t.t), Ahmad Damanhuri (2006), Al-Habannakah (1993), Al-Quasini (t.t), Al-Shanqiti (2007), Mahdi Fadhlullah (1998), Murtadha Mutahhari (2011), and H.Syukriadi Sambas (2003), noted that Islamic Logic comprises three major components namely tasawwur, tasdiq and al-Istidlal. These three components are akin to a complete cycle that is mutually complementary in orientation. Tasawwur refers to the approach that highlights which objects and concepts are subject to analysis. Next, tasdiq functions to provide the framework within which objects and concepts identified in tasawur are analyzed to ascertain their Truth or otherwise. Finally al-Istidlal functions as the arbiter of truth and fallacy in the cycle.

Thirdly, the application of logic should be designed to strengthen the Islamic framework rather than reinforce the Western framework. In other words, all arguments and postulates made must originate from Islamic principles, provenance and contemporary scholars and must be presented in a logical manner. Conversely, if arguments and ratiocinations derived from the al-Quran and the Sunnah (Traditions) are used to justify Western frameworks, it will not strengthen Islam. Instead such an approach will further reinforce the Western framework as whatever ulterior motives envisaged by the West is further burnished via justification with Islamic postulates and arguments. This process called Quranisation or ayatization should be avoided as the ultimate goal of upholding the Islamic framework is to reduce reliance on Western Logic frameworks and propositions.

Fourthly, logic is the means to an end, not the end itself. In other words, the goal should always be the 
proselytization of Islam and its teachings. Hence, if it is clear that each and every recourse to Logic in contemporary Islamic discourse is a means to an end, then priority can be accorded towards proselytization efforts and endeavours to enhance faith rather than attempting to rationalize all things Islamic so as to prevail in polemics. In fact, some concepts and precepts in Islam are revealed as they are and need no further ratiocination.

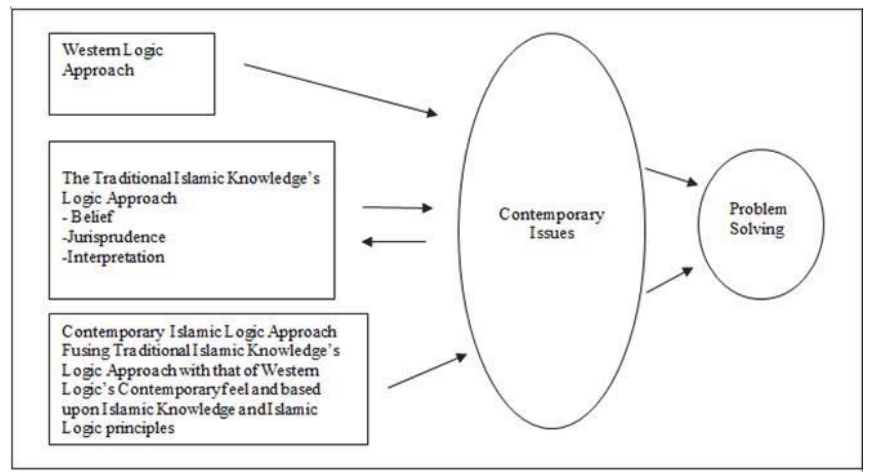

Figure 1: Proposed Contemporary Islamic Logic Approach (CILA)

Figure 1 illustrates three Logic approaches, namely, the Western Logic approach, the Traditional Islamic Knowledge approach and the proposed Contemporary Islamic Logic Approach. Essentially, the Western Logic approach attempts to resolve a problem via Reason alone and this invariably involves any resolution to be framed within the western paradigm.

In contrast, the Islamic Logic approach adopts a traditional Islamic knowledge perspective when deliberating contemporary issues. Although the approach utilizes logic in its dissection of such contemporary issues, the discussion is nevertheless circumscribed by the conventions of traditional Islamic knowledge and consequently does not address the actual problems in Reality. Hence, it is proposed that a contemporary approach, that involves the amalgamation of traditional Islamic knowledge and Islamic Logic with the argumentative features of Western logic known as the Contemporary Islamic Logic Approach (CILA), be adopted by Muslim scholars to reach out and connect with contemporary citizenry in efforts to analyse and resolve contemporary problems in accordance with Islamic precepts without ignoring the discourse dynamics of contemporary society.

\section{Conclusions}

Any discussion regarding the use of logic in contemporary Islamic Discourse will by default yield at least three outcomes. First, there is a necessity for a new approach in contemporary times regarding the proselytization of Islam. Essentially such an approach involves the harmonisation of traditional Islamic Logic with the Western Logic paradigm.Termed Contemporary Islamic Logic Approach, any such hybrid fusion of two different traditions of Logic should nevertheless comply with aforementioned four rules in the preceding section. Secondly, it is envisioned that a Contemporary Logic that defines Islam in an easily comprehensible language that is accessible to the West can help to resolve contemporary issues more effectively without in any manner whatsoever diluting the true teachings of Islam. Finally, such a discussion would yet again indirectly underline the fact that the learning/acquisition of Islamic logic is of utmost importance in contemporary times and hence should not be sidelined.

\section{Acknowledgement}

This paper is part of various output from a research entitled The Art of Reasoning in Islamic Research Methodology [(RUI)1001/CISDEV/816207] and was funded by Research University Individual (RUI) Grant, Universiti Sains Malaysia (2012-2015).

The Author is indebted to Mr Ahmad Sofwan Nathan Abdullah from School of Languages, Literacy and Translation, Universiti Sains Malaysia for translating the original and reviewing the translated manuscript. 


\section{References}

Al-Quranul Karim.

'Abd al-Hadi al-Fadli. t.t. Mudzakkirat al-Mantiq. Iran: Mu'assasat Dar al-Kitab al-Islami.

'Abd al-Wahhab Khallaf. 1956. 'IIm Usul al-Figh. Kaherah, Mesir: Maktabat al-Da'wat al-Islamiyyat Syabab al-Azhar.

Abdul Halim Mahmud. 1995. Islam dan Akal. Kuala Lumpur: Dewan Bahasa dan Pustaka.

Abdul Rahman Abdullah. 2007. Falsafah Dan Kaedah Pemikiran. Kuala Lumpur: Utusan Publications \& Distributors Sdn Bhd.

Adler, E. S. \& Clark, R. 2008. How It's Done: An Invitation to Social Research. Belmont: Thomson Wadsworth.

Ahmad Damanhuri. 2006. 'Idah al-Mubham Fi al-Ma'ani al-Sullam. Beirut: Maktabat al-Ma'arif.

Al-Akhdari, 'Abd al-Rahman Bin al-Saghir. 2007. Al-Sullam al-Mantiq. Beirut: Dar al-Kutub al-'Ilmiyyah.

Al-Ghazali, Abu Hamid. 1993. Tahafut al-Falasifah. Kuala Lumpur: Dewan Bahasa dan Pustaka.

Al-Ghazaliy, Abu Hamid. 2003. Al-'Iqtisad Fi al-'I'tiqad. Beirut: Dar Qutaibah.

Al-Ghazaliy, Abu Hamid. 2010. 'Ihya' al-'Ulum al-Din. Beirut: Dar Sadir.

Al-Ghazaliy, Abu Hamid. t.t. Al-Mustasfa Min 'Ilmi al-'Usul. Beirut: Dar al-Arqam Bin Abi al-Arqam.

Al-Habannakah, 'Abd al-Rahman Hasan. 1993. Dawabit al-Ma'rifah. Damshik: Dar al-Qalam.

Al-Harithi, Wa'el Bin Sultan Bin Hamzah. 2010. "Ilaqat 'Ilm al- 'Usul al-Figh Bi 'Ilm al-Mantiq: Dirasat Tahliliyyah Tarikhiyyah. Tesis Sarjana Usul Fiqah yang diserahkan kepada Kuliyyah Syariah dan Pengajian Islam, Universiti Umm al-Qura.Tidak diterbitkan.

Al-Jurjani, 'Ali Muhammad al-Sharif. 1975. Al-Ta'rifat. Beirut: Maktabat Lubnan.

Al-Katibi, Najm al-Din 'Ali Ibn 'Umar Al-Qazwini. 1998. Al-Shamsiyat Fi al-Qawa'id al-Mantiqiyyah. Beirut: al-Markaz al-Thaqafi al-'Arabi.

Al-Muhasibi, al-Harith Ibn 'Asad. 1971. Al-'AqI Wa Fahmi al-Qur'an. Beirut: Dar al-Fikr.

Al-Qardhawi, Yusuf. 1998. Al-Qur'an Berbicara Tentang Akal dan IImu Pengetahuan, terj.Abdul Hayyie al-Kattani, Irfan Salim \& sochimien MH. Jakarta: Gema Insani Press.

Al-Quwasini, Hasan Darwish. t.t. Sharh 'Ala Matn al-Sullam Fi al-Mantik.Rabat: Maktabat Dar al-'Iman.

Al-Sa'diy, Abdul Malik Abdul Rahman. 2007. Sharh al-Nasafiyyat Fi al-'Aqidat al-Islamiyyah. Amman: Matba'at al-Azhar.

Al-Shafi'iy, Muhammad 'Idris. t.t. al-Risalah. Misr: Maktabat al-'IImiyyah.

Al-Shanqiti, Muhammad Bin Mahfuz Bin Mukhtar Fall. 2007. Al-Dau'u al-Mashriq 'Ala Sullam al-Mantiq. Beirut: Dar al-Kutub al-'Ilmiyyah.

Al-Shatibiy, Abu Ishak. 1994. al-Muwafaqat. Beirut: Dar al-Ma'rifah.

Al-Suyutiy, Jalal al-Din 'Abd al-Rahman Bin Abi Bakr 2008. Saun al-Mantiq Wa al-Kalam 'an Fann al-Mantiq Wa al-Kalam. Beirut: Dar alKutub al-'Ilmiyyah.

Babbie, E. 2013. The Practice of Social Research, 13 th ed. United State of America: Wadsworth Cengage Learning.

Bacon, Francis. 1955. Novum Organum Scientiarum. New York: P. F. Collier and Son.

Blaikie, Norman. 2008. Analyzing Quantitative Data. London: Sage Publication Ltd.

Blaikie, Norman. 2009. Designing Social Research. Cambridge: Polity Press.

Barnes, Jonathan. 1991. Aristotle. Ampang: Dewan Bahasa dan Pustaka.

Elster, Jon. 2010. Explaining Social Behaviour: More Nuts and Bolts for Social Sciences. Cambridge: Cambridge University Pess.

Gabbay, Dov M. \& Woods, John. (Eds.). 2008. Handbook of The History of Logic (Vols. 1-3). Amsterdam: North-Holland.

Gerring, J. 2001. Social Science Methodology: A Critical Framework. United States of America: Cambridge University Press.

H. Syukriadi Sambas. 2003. Mantik Kaidah Berpikir Islami. Bandung: PT Remaja Rosdakarya.

Hamidah Abdulhamid. 1991. Pengantar Logik. Kuala Lumpur: Dewan Bahasa dan Pustaka.

Ibn Taymiyyah. 2005. Al-Radd 'ala al-Mantiqiyyin. Beirut: Mu'assasah al-Rayyan.

Ibn Taymiyyah. 2005. Naqd al-Mantiq. Kaherah: Maktabat al-Sunnat al-Muhammadiyyah.

Kelley, David. 1998. The Art Of Reasoning. New York: W.W. Norton Company \& Inc.

Lok Chong Hoe, Peter Gan Chong Beng \& Ratna Roshida Ab Razak. (2009). Pemikiran Kritis. Malaysia: McGraw-Hill.

Louay Safi. 1996. The Foundation of Knowledge-A Comparative Study in Islamic and Methods of Inquiry. Kuala Lumpur: International Islamic University Malaysia Press.

Mahdi Fadlullah. 1998. Al-Shamsiyat Fi al-Qawa'id al-Mantiqiyyah. Beirut: al-Markaz al-Thaqafi al-'Arabi.

Mat Rofa Ismail. 1994. Mantik, Matematik dan Budaya IImu: Pendekatan Bersepadu dalam Tradisi Pengajian Islam. Kuala Lumpur: Penerbit Universiti Malaya.

Mat Rofa Ismail. 1997. Mantik Dalam Babak Pemikiran IImiah Tamadun Manusia. Kuala Lumpur: Dewan Bahasa dan Pustaka.

Mat Rofa Ismail. 2006. Falsafah Sains: Pendekatan Kualitatif. Kuala Lumpur: Dewan Bahasa dan Pustaka.

Mat Rofa Ismail. 2012a. "Penguasaan IImu Mantik dan Matematik sebagai Tuntutan Agama: Memanfaatkan Sejarah Keilmuan Islam", dlm. Azrina Sobian, (Ed.). Membina Kekuatan Sains Di Malaysia. Kuala Lumpur: Penerbit IKIM.

Mat Rofa Ismail. 2012b. "Perluasan Domain Sains: Ke arah Kajian sains yang mengasyikkan", dlm. Azrina Sobian, (Ed.). Membina Kekuatan Sains Di Malaysia. Kuala Lumpur: Penerbit IKIM.

Mat Rofa Ismail. 2013. "Prinsip Ketersebaban dan Fahaman Positivisme", This paper was presented at the Seminar IImu Mantik 2013, jointly organized by the Contemporary Islamic Studies Faculty (FKI),Universiti Sultan Zainal Abidin (UniSZA), Institut Pengajian Matematik (INSPEM), Universiti Putera Malaysia, and the Malaysian Mathematics Association at the Gong Badak Campus of Universiti Sultan Zainal Abidin, on 17-18 September.

Mayer, Frederick. 1950. A History of ancient and medieval philosophy. New York: American Books Co.

Mills, J.S. 1850. A System of Logic. New York: Harper \& Brothers Publishers. 
Mohd Fauzi Hamat. 2005. Ketokohan al-Ghazali Dalam Bidang Logik. Kuala Lumpur: Penerbit Universiti Malaya.

Muhammad Syukri Salleh. 2008. "Kaedah Penyelidikan Berteraskan Islam: Keperluan, Kedudukan dan Hala Tuju". Pemikir, No. 54, October-Disember, p. 133-164.

Muhammad Syukri Salleh. 2011. "Ke Arah Kaedah Penyelidikan Berteraskan Islam", dlm. Zakaria Bahari, et. al., (Eds.), Pengurusan IImu, Ekonomi dan Pembangunan Berteraskan Islam. Pulau Pinang: Penerbit Universiti Sains Malaysia.

Muhammad Syukri Salleh. 2012. "Religousity in Development: A Theoretical Construct of an Islamic-Based Development", International Journal of Humanities and Social Science, 2(14), p. 266-274.

Muhammad Syukri Salleh. 2013. "Concepts in Islamic Economics Revisited: The Case of Poverty". Proceedings pada Workshop On Basic Concepts and Thoughts in Islamic Economics, anjuran ILKE Association of Science Culture Education, Association of Entrepreneuship and Business ethics (IGIAD) dan Scientific Studies Association (ILEM) di Istanbul, Turki, 2-3 Mac. Diterbitkan Semula Dalam Siri Kertas ISDEV No. 48.

Murtada Mutahhari. 2011. Al-Mantiq. Beirut: Dar al-Wala'.

Muzaffar Iqbal. 2009. The Making of Islamic Science. Kuala Lumpur: Islamic Book Trust.

Myrdal, Gunnar. 1969. Objectivity in Social Research. Connecticut: Wesleyan University Press.

Neuman, W. Lawrence. 2011. Social Research Methods: Qualitative and Quantitative Approaches, $7^{\text {th }}$ ed. Boston: Allyn and Bacon.

Ragin, Charles C. and Amoroso, Lisa M. 2011.Constructing Social Research: The Unity and Diversity of Method. United States of America: Pine Forge Press (Sage).

Rehana Masrur \& Masrur Alam Khan 2007. "Quantifying the Unquantifiable: Developing Quality Measures For Affective Objectives", Masalah Pendidikan, 30(2), p. 19-32.

Reevany Bustami, Eleesya Nasruddin \& Norman Blaikie. 2006. Lima Falsafah Penyelidikan. Pulau Pinang: KnowledgeCraftsmen.

Russell, Bertrand. 1993. Sejarah Falsafah Barat. Kuala Lumpur: Dewan Bahasa dan Pustaka.

Sa'id Fudah. 2002. Tad'im al-Mantiq. Amman: Dar al-Razi.

Shahir Akram Hassan. 2011. "Kaedah Penaakulan Dalam Penyelidikan Lazim", paper presented at The 6 $6^{\text {th }}$ ISDEV International Graduate Workshop (INGRAW 2011), jointly organized by the Center for Islamic Development Studies (ISDEV), the School of Social Sciences dan Institute of Graduate Studies , Universiti Sains Malaysia, Pulau Pinang, University Conference Hall , 11-12 Oktober.

Sulaiman Hj Noordin. 1992. Sains, Falsafah dan Islam. Bangi: Pusat Pengajian Umum, Universiti Kebangsaan Malaysia.

Teare, Barry. 2006. Problem-solving and Thinking Skills Resources for Able and Talented Children. London: Network Continuum Education.

Walbridge, J. 2011. God and Logic in Islam: The Caliphate of Reason. Cambridge: Cambridge University Press.

Weathington, Bart L., Cunninghan, Cristopher J. L. \& Pittenger, David J. 2010. Research Methods For The Behavioral And Social Sciences. New Jersey: John Wiley \& Sons.

Ya'qub al-Bahuthain. 1998. Al-Qawa'id al-Fiqhiyyah. Riyadh: Maktabat al-Rushd.

Ya'qub al-Bahuthain. 2001. Turuq al-Istidlal Wa Muqaddamatiha 'Inda al-Manatiqah Wa al-'Usuliyyin. Riyadh: Maktabat al-Rushd. 